\title{
16
}

\section{Fire in the Wildland-Urban Interface}

\author{
D. Evan Mercer and Wayne Zipperer
}

\begin{abstract}
In this chapter we provide an overview of the socio-economic and ecological effects and trends of wildfire in the WUI, methods for assessing wildfire risk in the WUI, approaches to managing the wildfire problem including fuels management, home construction and design, and community action programs. This overview is combined with two case studies analyzing wildfire risk and the use of prescribed fire to reduce that risk in the Florida wildland-urban interface.
\end{abstract}

The federal government's expenditures for fighting wildfire more than tripled (in inflation-adjusted dollars) between 1996 and 2007, increasing from \$984 million in 1996 to \$3 billion in 2007 (U.S. Government Accountability Office, 2009) (Fig. 16-1). Between 1999 and 2010, an average of 1179 residences, 1156 outbuildings, and 42 businesses were destroyed by wildfire annually (National Institute of Standards and Technology, 2010), and each year an average 21 firefighters die fighting wildfires (Rasker, 2009). One cause of the increasing costs associated with wildfire has been the rapid growth of the wildland-urban interface and the concomitant increase in the number of citizens and property in wildfire-prone areas. For example, the USDA Office of the Inspector General (2006) estimated that protecting lives and property in the wildland-urban interface accounts for 50 to $95 \%$ of the costs of fighting wildfires.

Although the wildland-urban interface covers only $9 \%$ of the land in the 48 contiguous states, it contains 39\% of all houses (Hammer et al., 2008). With housing starts three times greater in the wildland-urban interface than in non-wildland-urban interface areas, the USDA Office of Inspector General (2006) predicted that there will be a $40 \%$ increase in the number of homes in the wildland-urban interface by the year 2030. Exacerbating the future wildland-urban interface wildfire problem is climate change, which is also projected to result in greater incidence of future wildfire (Bachelot et al., 2007; Westerling and Swetnam, 2003; Westerling et al., 2006). Furthermore, the USDA Office of Inspector General (2006) reported that many wildland-urban interface residents underinvest in mitigation actions, assuming government emergency services will protect them from wildfire and insurance or federal disaster assistance will cover any property losses. As a result, wildfire management in the wildland-urban interface has become a major focus of federal, state, and local government agencies struggling to develop policies, programs, and regulations to reduce the growing costs of wildfire (USDA Office of Inspector General, 2006).

\footnotetext{
D. Evan Mercer, USDA Forest Service, Southern Research Station, 3041 E. Cornwallis Road, Research Triangle Park, NC 27709 (emercer@fs.fed.us); Wayne Zipperer, USDA Forest Service, University of Florida, Bldg. 164, Mowry Road, Gainesville FL 32611-0906 (wzipperer@fs.fed.us).

doi:10.2136/2012.urban-rural.c16
}

Urban-Rural Interfaces: Linking People and Nature, David N. Laband, B. Graeme Lockaby, and Wayne Zipperer, editors Copyright (C) 2012. American Society of Agronomy, Soil Science Society of America, Crop Science Society of America 5585 Guilford Rd., Madison, WI 53711-5801, USA. 
The focus of this chapter is an examination of the issues associated with wildfire in the wildland-urban interface. We examine the socioeconomic and ecological effects and trends of wildfire in the wildland-urban interface, methods for assessing wildfire risk in the wildland-urban interface, and approaches to managing the wildfire problem, including fuels management, home construction and design, and community action programs. We also provide two case studies from Florida that serve as examples of using wildfire production function analysis to assess wildfire risk and optimize fuels management in the wildland-urban interface.

\section{Effects of Wildfire in the Wildland-Urban Interface}

The rapid growth of the wildland-urban interface over the last few decades is the primary factor in the increasing costs associated with destruction of homes, property, and human life by wildfire. For example, wildland-urban interface fires have accounted for 9 of the 25 most costly fires in U.S. history (Ahrens, 2010). Table 16-1 shows losses for the 10 most destructive wildland fires, all of which occurred in the wildland-urban interface. Five of the 10 costliest wildfires in the United States occurred during the 2000s and four in the 1990s. Damages from the 10 largest wildland fires grew from $\$ 3.98$ billion in the 1990s to $\$ 6.2$ billion in the 2000s (National Fire Protection Association, 2009).

The total area burned by wildland fires has also increased during the last two decades. Figure 16-2 shows the number of wildland acres burned and the 5-yr rolling average of wildland acres burned between 1985 and 2009. Given the stochastic nature of wildfire, the area burned varies widely from year to year. However, the 5 -yr rolling average shows that the area burned by wildfire has exhibited a consistent increasing trend over the past $25 \mathrm{yr}$ (Ahrens, 2010). Federal agencies responded to an average 79,000 wildfires annually, while local fire departments responded to an average of 356,800 brush, grass, and forest fires per year that burned 4800 buildings annually between 2004 and 2008 (Ahrens, 2010). Wildfires occur primarily in the West and Southeast. For example, $75 \%$ of all acres burned by wildfire in 2007 occurred in 14 contiguous Western states, while Florida and Georgia accounted for $16 \%$ of wildfire acres burned in 2007 (Hammer et al., 2008).

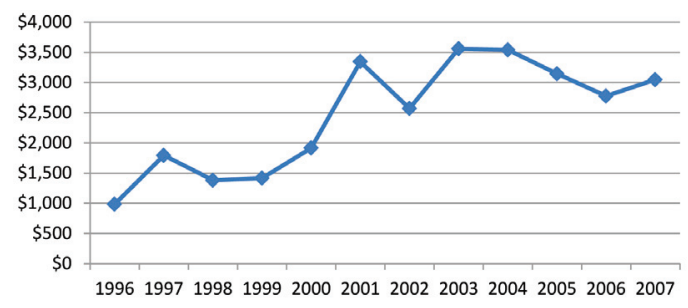

Fig. 16-1. Forest Service and Interior Department Wildfire Expenditures 1996-2007 in millions of dollars (2007) (U.S. Government Accountability Office, 2009)

Over much of the past century, wildland fire suppression, the primary policy for public lands, has caused a number of profound ecological changes. Donovan and Brown (2007) identified three direct changes: (i) a shift in composition from fire-tolerant to less fire-tolerant species, (ii) an increase in stem density, and (iii) a subsequent shift in wildlife composition and structure. In addition, with a buildup in fuel loads, wildland fires became more extreme and intense, often killing not only the existing stand composition, but also the seed bank, thus limiting regeneration. In fact, fire suppression has been so successful that wildland fires have become more difficult and expensive to control (Donovan and Brown, 2007). Urban development has only added to the problem by compounding the difficulty of managing fire in an urbanizing landscape, which increases the cost of using fire to reduce risk. With development, fire suppression is critical to minimizing structural ignitions. As with wildlands, the outcome is an increasing buildup of fuels adjacent to developed areas (Yoder et al., 2004).

Fire suppression and buildup of fuel loads are especially problematic in rapidly growing forests, such as those that occur in the Southeast, where treatment may need to occur every 3 to 5 yr. It should be noted that the Southeast also has the highest density of interface lands in the nation (Radeloff et al., 2005). Consequently, fire managers are faced with a daunting challenge of trying to manage fire-prone ecosystems that have experienced decades of suppression and reducing risk to humans in interface communities (Donovan and Brown, 2007).

The extent of ecological change and the opportunity for restoration depends on the condition of the fire-dependent ecosystem. Schmidt et al. (2002) identified three conditions classes based on departure from historical fire regimes (Table 16-2). Of particular interest to the interface is condition class 3 in which fire regimes are significantly altered from their historic ranges. Because 


\begin{tabular}{|c|c|c|c|c|c|}
\hline Rank & Event & $\begin{array}{l}\text { Loss in year fire } \\
\text { occurred }\end{array}$ & $\begin{array}{l}\text { Loss in } 2008 \\
\text { dollars }\end{array}$ & Lives lost & $\begin{array}{l}\text { Homes } \\
\text { damaged }\end{array}$ \\
\hline 1 & $\begin{array}{l}\text { Oakland Fire Storm } 1991 \\
\text { Oakland, CA }\end{array}$ & $\$ 1.5$ billion & $\$ 2.3$ billion & 25 & 3354 \\
\hline 2 & $\begin{array}{l}\text { The Southern California Firestorm 2007, } \\
\text { San Diego County, CA }\end{array}$ & $\$ 1.8$ billion & $\$ 1.9$ billion & 9 & 1500 \\
\hline 3 & $\begin{array}{l}\text { "Cedar" Wildland Fire } 2003 \\
\text { Julian, CA }\end{array}$ & $\$ 1.1$ billion & $\$ 1.2$ billion & 15 & 2232 \\
\hline 4 & $\begin{array}{l}\text { "Cerro Grande" Wildland Fire } 2000 \\
\text { Los Alamos, NM }\end{array}$ & $\$ 1.0$ billion & $\$ 1.2$ billion & 0 & 400 \\
\hline 5 & $\begin{array}{l}\text { "Old" Wildland Fire } 2003 \\
\text { San Bernardino, CA }\end{array}$ & $\$ 975$ million & $\$ 1.1$ billion & 6 & 993 \\
\hline 6 & $\begin{array}{l}\text { Southern California Wildfires of November } 2008 \\
\text { Sacramento, CA }\end{array}$ & $\$ 800$ million & $\$ 800$ million & 0 & 900 \\
\hline 7 & $\begin{array}{l}\text { "Laguna Beach Fire" } 1993 \\
\text { Orange County, CA }\end{array}$ & $\$ 528$ million & $\$ 777$ million & 0 & 441 \\
\hline 8 & $\begin{array}{l}\text { Florida Wildland Fires } 1998 \\
\text { Central and Northeast Florida }\end{array}$ & $\$ 395$ million & $\$ 519$ million & 0 & 340 \\
\hline 9 & $\begin{array}{l}\text { Forest Fire } 1918 \\
\text { Cloquet, MN }\end{array}$ & $\$ 35$ million & $\$ 496$ million & 453 & 52000 \\
\hline 10 & $\begin{array}{l}\text { "Paint Fire" Goleta } 1990 \\
\text { Santa Barbara, CA }\end{array}$ & $\$ 237$ million & $\$ 386$ million & $n / a$ & $\mathrm{n} / \mathrm{a}$ \\
\hline
\end{tabular}

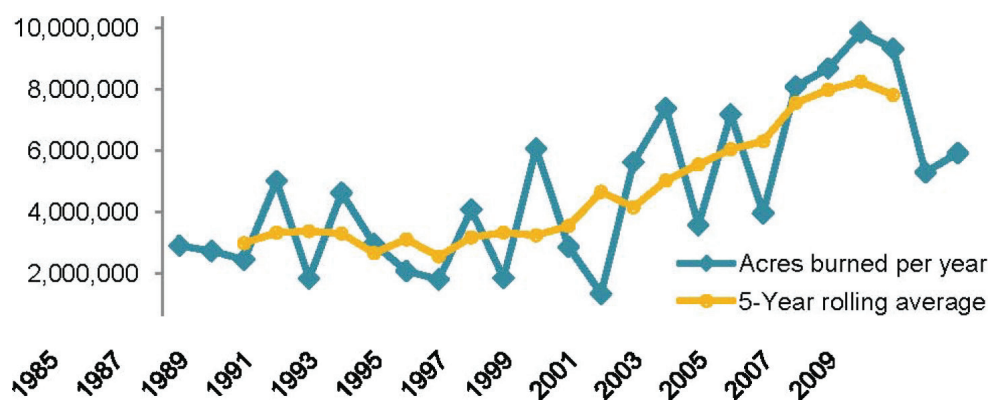

Fig. 16-2. Number of wildland acres burned in fires under jurisdiction of federal agencies, 1985-2009 (Ahrens, 2010).

of the high probability of a catastrophic fire in condition class 3 , mechanical or hand treatments are necessary before prescribed fire can be used to restore the fire regime. Unfortunately the cost of mechanical and hand treatments is expensive, as compared to prescribed fire (Donovan and Brown, 2007). Subsequently, because of the fire risk to humans, interface communities in condition class 3 and those communities that cannot employ prescribed fire to control fuel loads must rely on mechanical and hand treatments to reduce fire hazards. Unfortunately, these treatments can usurp a significantly greater proportion of a fire management agency's fire fighting budget, thus leaving less funds to manage wildlands. A potential result may be an increased risk for catastrophic fires in the future. Furthermore, interface communities have their own suite of plant species that can influence not only biodiversity (see Chapter 6, Reed et al., 2012, this volume) but also fire behavior (White and Zipperer, 2010).

\section{Wildfire Risk Assessment in the Wildland-Urban Interface}

Wildfire risk, the expected net value change resulting from future wildfire, is calculated by multiplying the probability of a fire at a specific intensity and location by the resulting net present value of the change in financial, ecological, and social value (e.g., Bachmann and Allgöwer, 2001; Brillinger, 2003; Finney, 2005). In addition to the expected damages from wildfire, the expected effects of weather, ecological conditions, wildfire suppression, fuels management, and other mitigation activities should also be included in calculating the expected net value change for analyzing wildfire risk (Agar et al., 2006).

Federal, state, and local governments have made significant efforts to identify, quantify, and prioritize communities at risk from wildfire (e.g., Glickman and Babbitt, 2001; Governor's Wildfire Response and Mitigation Review Committee, 1998; Steelman and Kunkel, 2004; USDA Forest Service, 2000, 2004). At the community level, fire 
Table 16-2. Fire regime current condition class descriptions (Schmidt et al., 2002).

\begin{tabular}{|c|c|c|}
\hline Condition class & Fire regime & Example management option \\
\hline Condition class 1 & $\begin{array}{l}\text { Fire regimes are within a historical range, and the risk of } \\
\text { losing key ecosystem components is low. Vegetation } \\
\text { attributes (species composition and structure) are intact } \\
\text { and functioning within an historical range. }\end{array}$ & $\begin{array}{l}\text { Where appropriate, these areas can be } \\
\text { maintained within the historical fire } \\
\text { regime by treatment such as fire use. }\end{array}$ \\
\hline Condition class 2 & $\begin{array}{l}\text { Fire regimes have been moderately altered from their } \\
\text { historical ranges. The risk of losing key ecosystem com- } \\
\text { ponents is moderate. Fire frequencies have departed from } \\
\text { historical frequencies by one or more return intervals } \\
\text { (either increasing or decreasing). This results in moderate } \\
\text { changes to one or more of the following: fire size, inten- } \\
\text { sity, and severity, and their landscape patterns. Vegetation } \\
\text { attributes have been moderately altered from their his- } \\
\text { torical range. }\end{array}$ & $\begin{array}{l}\text { Where appropriate, these areas may need } \\
\text { moderate levels of restoration treat- } \\
\text { ments, such as fire use and hand or } \\
\text { mechanical treatments to be restored to } \\
\text { historical fire regime. }\end{array}$ \\
\hline Condition class 3 & $\begin{array}{l}\text { Fire regimes have been significantly altered from their } \\
\text { historical range. The risk of losing key ecosystem com- } \\
\text { ponents is high. Fire frequencies have departed from } \\
\text { historical frequencies by multiple return intervals. This } \\
\text { results in dramatic changes to one or more of the follow- } \\
\text { ing: fire size, intensity, and severity, and their landscape } \\
\text { patterns. Vegetation attributes have been significantly } \\
\text { altered from their historical range. }\end{array}$ & $\begin{array}{l}\text { Where appropriate, these areas may need } \\
\text { high levels of restoration treatment, } \\
\text { such as hand or mechanical treatments, } \\
\text { before fire can be used to restore the } \\
\text { historical fire regime. }\end{array}$ \\
\hline
\end{tabular}

risk has been evaluated in terms of the spatial context of the community to provide detailed information on spatial patterns of fire breaks, treated and untreated areas, and structural density, proximity of wildland fuel types and loads, and accessibility for fire fighting equipment. These data layers are joined to create fire hazard maps. For instance, Menakis et al. (2003) created a fire hazard map by layering three GIS data layers: Potential Fire Exposure Map, which mapped fire intensity of the vegetation; Extreme Fire Weather Potential, which identified potential extreme weather conditions, and Housing Density which mapped potential fire losses in the event of a wildland fire. Similarly, Theobald and Romme (2007) combined wildland fire hazard data layers, housing density, and land-cover data sets to create vulnerability maps to identify high risk areas.

Although fire hazard maps provide essential information to identify areas of risk, we currently do not have models that project how fires spread through a wildland-urban interface community. In fact, the interface is a unique intersection of natural and anthropogenic fuels that alter wildland fire dynamics. An examination of existing fire models illustrates this point. BehavePlus, FLAMMAP, and other fire models do not account for structures or their density in predicting fire spread and behavior (Mell et al., 2010). Likewise, models of structural fires do not account for vegetation. To fully comprehend fire dynamics in the interface, models of wildland fires need to intersect with models of structural fires. A program at the National Institute of Standards and Technology is focusing on creating a physics-based model to capture the nuances of fire dynamics in the interface (Mell et al., 2010). The model links topography, local meteorology, three-dimensional distribution of natural and anthropogenic fuels, and their properties.

While significant progress has been made in assessing wildfire risks at fine spatial scales (e.g., the Florida Fire Risk Assessment System; McLellan and Brenner, 2003), few risk assessments include the crucial social and economic factors influencing wildfire risk in the wildlandurban interface. Solving the wildland-urban interface wildfire problem requires identifying linkages among ecological, social, and physical factors affecting wildfire and understanding how social policies and socioeconomic conditions alter those linkages at different spatial and temporal scales (Zipperer, 2002). Wildfire economists use wildfire production functions (WPFs) to estimate these linkages empirically (Prestemon et al., 2008).

Wildfire production functions are quantitative models that predict the spatial and temporal variability in wildfire extent and intensity, given different ecological, social, and economic conditions and management inputs. Wildfire production function modeling allows empirical analysis of the relative impacts of human and nonhuman factors on wildfire. The results are used to forecast wildfire risk under varying conditions and evaluate tradeoffs between alternative wildfire intervention programs and policies. Thus, WPFs can provide critical information for determining the most efficient and effective allocation of resources between wildfire 
awareness programs, fuel treatments, preparedness (pre-suppression), and suppression.

Most importantly, wildfire production analysis provides an approach to empirically answer questions such as: Where are wildfires most likely to occur? How are the extent and intensity of wildfires distributed within the wildland-urban interface? Which wildland-urban interface characteristics (ecological, economic, demographic, and social) are more likely to be associated with wildfire? Which communities in the wildlandurban interface are most at risk from wildfire. Table 16-3 presents an overview of the four general categories of wildfire production function models, including references to published studies. The brief descriptions of the models below are derived from Mercer and Prestemon (2005) and Prestemon et al. (2008).

\section{Fire Event Models}

Wildfire event models typically relate ignitions (counts or occurrences over time and/or space) as a function of the conditions surrounding the ignition point. Wildfire ignition processes can be modeled in several ways. Most common are the Poisson approaches (e.g., Poisson, negative binomial), which relate the observed counts of ignitions to a set of spatially arranged covariates based on a Poisson process (Greene, 1997). Point process models shrink the size of wildfires to specific ignition points to estimate the relationship between ignition points and spatially arranged covariates. When used to identify sites with high wildfire risk and develop probability of ignition maps, fire event models can provide critical information for improving initial attack success rates by optimizing the prepositioning of suppression resources before the fire season.

\begin{tabular}{|c|c|c|c|c|c|}
\hline Model & $\begin{array}{l}\text { Dependent } \\
\text { variable(s) }\end{array}$ & Common types & Advantages & Disadvantages & Examples \\
\hline $\begin{array}{c}\text { Fire event } \\
\text { models }\end{array}$ & Ignitions & $\begin{array}{l}\text { Statistical: } \\
\text { Probit/logit } \\
\text { Poisson } \\
\text { Negative bino- } \\
\text { mial } \\
\text { Point process } \\
\text { Nonparametric } \\
\text { Survival models }\end{array}$ & $\begin{array}{l}\text { Can incorporate spatially and } \\
\text { temporally dependent or } \\
\text { autoregressive relationships. } \\
\text { Useful when suppression } \\
\text { includes costs associated } \\
\text { with ignitions. } \\
\text { Can identify time and location } \\
\text { of high wildfire risk. }\end{array}$ & $\begin{array}{l}\text { Low statistical } \\
\text { power. } \\
\text { Underdeveloped } \\
\text { statistical } \\
\text { methods. }\end{array}$ & $\begin{array}{l}\text { Cox (1972) } \\
\text { Donoghue and Main (1985) } \\
\text { Gill et al. (1987) } \\
\text { Garcia et al. (1995) } \\
\text { Pye et al. (2003) }\end{array}$ \\
\hline $\begin{array}{l}\text { Individual fire } \\
\text { extent }\end{array}$ & $\begin{array}{l}\text { Area burned } \\
\text { or not } \\
\text { burned by a } \\
\text { single fire }\end{array}$ & $\begin{array}{l}\text { FARSITE } \\
\text { BEHAVE } \\
\text { Statistical: } \\
\text { Distance function } \\
\text { (multi-output) } \\
\text { Least squares } \\
\text { (single output) }\end{array}$ & $\begin{array}{l}\text { Useful for evaluating influence } \\
\text { of suppression resources, } \\
\text { fuels levels, and weather on } \\
\text { burned area. }\end{array}$ & $\begin{array}{l}\text { May be unsuitable } \\
\text { for statistical } \\
\text { analyses. } \\
\text { Often ignore } \\
\text { spatial and } \\
\text { temporal } \\
\text { spillovers } \\
\text { of resource } \\
\text { decisions. }\end{array}$ & $\begin{array}{l}\text { Davis and Cooper (1963) } \\
\text { Finney (1998) } \\
\text { Andrews and Bevins (1999) } \\
\text { Finney and Andrews (1999) }\end{array}$ \\
\hline $\begin{array}{l}\text { Aggregate fire } \\
\text { extent }\end{array}$ & $\begin{array}{l}\text { Area burned } \\
\text { or not } \\
\text { burned by } \\
\text { multiple } \\
\text { fires }\end{array}$ & $\begin{array}{l}\text { Statistical: } \\
\text { Principal compo- } \\
\text { nents } \\
\text { Canonical correla- } \\
\text { tion } \\
\text { Least squares }\end{array}$ & $\begin{array}{l}\text { Can be a collective risk model. } \\
\text { Useful for evaluating impact } \\
\text { of large-scale management } \\
\text { on wildfire. } \\
\text { Can be used to quantify pre- } \\
\text { suppression resource needs. }\end{array}$ & $\begin{array}{l}\text { Not applicable } \\
\text { for economic } \\
\text { optimization } \\
\text { models at } \\
\text { fine spatial or } \\
\text { temporal scales. }\end{array}$ & $\begin{array}{l}\text { Barnett and Brenner (1992) } \\
\text { Armstrong (1999) } \\
\text { Westerling et al. (2002) } \\
\text { Prestemon et al. (2002) }\end{array}$ \\
\hline Fire effects & $\begin{array}{l}\text { Intensity } \\
\text { Damage } \\
\text { Fuel con- } \\
\text { sumed } \\
\text { Severity }\end{array}$ & $\begin{array}{l}\text { Statistical: } \\
\text { Ordered logit/ } \\
\text { probit } \\
\text { Least squares }\end{array}$ & $\begin{array}{l}\text { Most useful when combined } \\
\text { with other model types. } \\
\text { Can statistically relate fire } \\
\text { intensity to area burned. } \\
\text { Can create total damage } \\
\text { or aggregate heat output } \\
\text { functions. }\end{array}$ & $\begin{array}{l}\text { Discrete nature of } \\
\text { some measured } \\
\text { effects leads to } \\
\text { low powered } \\
\text { statistical models. }\end{array}$ & Rideout and Omi (1990) \\
\hline $\begin{array}{l}\text { Combination } \\
\text { models }\end{array}$ & $\begin{array}{l}\text { Wildfire } \\
\text { area given } \\
\text { successful } \\
\text { ignition }\end{array}$ & $\begin{array}{l}\text { Statistical: } \\
\text { Heckman } \\
\text { Tobit } \\
\text { Extreme value } \\
\text { Pareto distribu- } \\
\quad \text { tions } \\
\text { Least squares }\end{array}$ & $\begin{array}{l}\text { Able to combine event and } \\
\text { extent models. } \\
\text { Useful for size-frequency } \\
\text { distribution analysis. } \\
\text { Useful for forecasting wildfire } \\
\text { extent for spatial-temporal } \\
\text { units. } \\
\text { Provides more complete } \\
\text { characterization of } \\
\text { aggregate wildfire activity. }\end{array}$ & $\begin{array}{l}\text { Large data } \\
\text { requirements. } \\
\text { May be difficult } \\
\text { to identify } \\
\text { influences of } \\
\text { covariates. } \\
\text { Spatiotemporal } \\
\text { population } \\
\text { of fires may } \\
\text { be difficult to } \\
\text { identify. }\end{array}$ & $\begin{array}{l}\text { Strauss et al. (1989) } \\
\text { Malamud et al. (1998) } \\
\text { Li et al. (1999) } \\
\text { Keeley et al. (1999) } \\
\text { Holmes et al. (2004) } \\
\text { Cumming (2001) }\end{array}$ \\
\hline
\end{tabular}




\section{Individual Fire Extent Models}

Individual fire extent models relate the area or change in area burned per unit time for a single wildfire to a wide range of explanatory variables. Alternatively, they can be used to analyze how the area burned within a time frame (e.g., a day) is related to variables expected to affect the rate of wildfire spread. Individual fire extent models provide information for evaluating the influences of suppression resources, weather, and fuels on the extent of areas burned by wildfire and for identifying the effectiveness of wildfire suppression resources and fuel conditions on wildfire extent. When used to statistically relate the daily change in area burned to available suppression resources, weather, fuels, and other covariates, the results can be an important input for larger-scale suppression effectiveness models and for optimization modeling of wildfire suppression at the individual fire level (Donovan and Rideout, 2003).

FARSIGHT (Finney, 1998; Finney and Andrews, 1999) and BEHAVE (Andrews and Bevins, 1999) are examples of simulation models that provide insights and predictions of how factors such as fuel, wind, topography, and moisture affect individual fire behavior. These models have enabled a deep understanding of fire behavior and have been useful in tactical applications, evaluating the effects of suppression inputs and nonpurchased inputs (weather, fuels, landscape features) on the spread of individual fires. FARSIGHT and BEHAVE are based on many of the same factors as wildfire risk models. However, the short run nature of these simulation models restricts their usefulness in identifying the broad spatial and long temporal scale dynamic effects of fire, fire suppression, vegetation management, weather patterns, and socioeconomic conditions on wildfire risk.

\section{Aggregate Extent Models}

These models generalize the individual fire models spatially and temporally and utilize many of the same variables. Typical covariates include quantities of suppression resources, weather and climate, ecological conditions, and fuel loads aggregated over space and time. Aggregate extent models can be used as collective risk models by expressing the dependent variable (e.g., area burned) as a proportion of the size of the spatial unit being considered. Collective wildfire risk and aggregate extent models are useful for evaluating how largescale management activities affect observed amounts of wildfire and measuring tradeoffs between different approaches to wildfire management. Models that include forecastable independent variables can be used to predict collective risk or aggregate extent, which can then be used to improve preparedness planning, firefighting resource allocations, and wildfire mitigation activities such as fuels management and home defense.

\section{Effects Models}

Wildfire production function effects models relate the effects of wildfire, such as intensity, damage, fuel consumed, severity, or ecological benefit to physical, ecologic, weather, management actions, and socioeconomic condition. For example, effects models can relate average fire flame length (e.g., 0.5, 1.0, or $2.0 \mathrm{~m}$ ) to hypothesized explanatory variables. When time is used as a numeraire, the models are able to relate measured rates of wildfire effects to variables of interest. The spatial and temporal limitations of effects models result in many of the same problems inherent in individual fire event models. For this reason, effects models are probably most useful in combination with other kinds of WPFs. For example, one approach would be to aggregate wildfire effects across large spatial and temporal scales and relate them to similarly aggregated explanatory variables.

\section{Combination Models}

Combination models incorporate elements of at least two of the four categories of wildfire production functions. For example, a wildfire spread model combines an event model with an individual fire extent model to predict the size of a wildfire, given a successful ignition or start. Alternatively, given data on the sizes and numbers of wildfires within a spatial-temporal aggregate, a probability density function (pdf) of fire sizes (size-frequency distributions and extreme value functions) can be created. Replicating this across spatial-temporal units, allows one to use auxiliary regressions and multivariate statistical techniques to compare the estimated parameters of the size-frequency distribution (slope and intercepts) or the extreme value function to variables of interest. Another example of a combination model is individual or collective wildfire damage extent models that incorporate elements of both wildfire character and extent. These models can be estimated for individual fires or for large spatial-temporal units, relating the amount of damage to a set of hypothesized covariates. Combination models are used primarily for forecasting aggregate wildfire area 
burned or expected damages over space and time. They can also be used to develop more complete characterizations of aggregate wildfire activity spatially and temporally. For example, size-frequency distribution models can be used to predict how management alternatives affect a range of wildfire damage (from low to catastrophic).

\section{Case Study I: Wildfire Risk Analysis in the Florida Wildland-Urban Interface}

In this section, we use a Florida case study to provide examples of applying production function analysis to assess wildfire risk and how wildland-urban interface characteristics influence wildfire activity. This case study was derived from Mercer and Prestemon (2005). The case study compares a fire event model of wildfire ignitions, an aggregate fire extent model, and a combined fire effect and aggregate extent model estimated with a cross-sectional, county level, time series panel data set from 1995 to 2001. The results are used to develop insights into how physical, managerial, and socioeconomic factors affect fire occurrence, area burned, and damages across broad spatial and temporal scales in the wildland-urban interface in Florida.

The fire event and aggregate extent models relate total wildfire ignitions and acreage burned per county per year to $12 \mathrm{yr}$ of previous wildfire extent, weather variables (the sea surface temperature anomalies El Niño and North Atlantic Oscillation), $3 \mathrm{yr}$ of past prescribed burns, and wildland-urban interface related socioeconomic factors (population, poverty rates, unemployment, housing density, and number of police). Mathematically they are defined as:

Fire extent model:

$$
\begin{aligned}
\ln \left(\frac{W_{i, t}}{F_{i}}\right) & =\sum_{i=1}^{I} a_{i} d_{i}+\sum_{j=1}^{J} b_{j} \ln \left(\frac{W_{i, t-j}}{F_{i}}\right) \\
& +\sum_{k=0}^{K} c_{k} \ln \left(\frac{B_{i, t-k}}{F_{i}}\right)+e_{1} E_{\mathrm{t}}+e_{2} E_{1998} \\
& +f G_{\mathrm{t}}+g H_{i, t}+h U_{i t}+l P_{i t}+m O_{i t}+\omega_{i, t}
\end{aligned}
$$

Fire effect model:

$$
\begin{aligned}
\ln \left(\frac{X_{i, t}}{F_{i}}\right)= & \sum_{i=1}^{I} a_{i} d_{i}+\sum_{j=1}^{J} b_{j} \ln \left(\frac{W_{i, t-j}}{F_{i}}\right)+\sum_{k=0}^{K} c_{k} \ln \left(\frac{B_{i, t-k}}{F_{i}}\right) \\
& +e_{1} E_{\mathrm{t}}+e_{2} E_{1998}+f G_{\mathrm{t}}+g H_{i, t}+h U_{i t}+l P_{i t} \\
& +m O_{i t}+\omega_{i, t}
\end{aligned}
$$

The fire extent and aggregate fire effect models only differ in the definition of the dependent variable. For the fire extent model, the dependent variable is the natural log of the acreage of wildfire in county $i$ in year $t\left(W_{i, t}\right)$ as a proportion of the total forested area (acres) in the county $\left(F_{j}\right)$. Similarly, the dependent variable in the fire effect model is the natural log of wildfire intensity-acres $\left(X_{i t}\right)$ relative to $F_{i}$. (The intensityacres variable was constructed by multiplying the number of acres burned at different fireline intensities by those intensity levels, summing these, and then dividing by the total forest area in county $i$ in year $t$. Fireline intensity is defined as the rate of heat energy released per unit time per unit length of the fire front [Kennard, 2004].) $W_{i t-j}$ is the areal extent (acres) of wildfire in county $i$ in fire year $t-j$; the $d_{i}$ values are dummies for the various counties; $B_{i, t-k}$ is the total area (acres) of prescribed burning permits issued in county $i$ in year $t-k ; E_{\mathrm{t}}$ is the Niño-3 sea surface temperature (Niño-3 SST) anomaly (see Brenner, 1991; Barnett and Brenner, 1992); $E_{1998}$ is a dummy variable to allow separate analysis of the effect of the Niño-3 SST anomaly for 1998 (given its extreme "Super El Niño" characteristics); $G_{t}$ is the sea surface temperature anomaly in degrees centigrade for the North Atlantic Oscillation (NAO); $H_{i, t^{\prime}} U_{i, t^{\prime}} P_{i, t^{\prime}}$ and $O_{i, t}$ are the housing density, unemployment rate, poverty rate, and number of police officers, respectively, in county $i$ in year $t$; and $\omega_{i, t}$ is a randomly distributed error term.

\section{Data}

The Florida Division of Forestry (FDF) provided detailed records for all silvicultural burn permits issued by the State of Florida and all wildland fires on non-federal lands reported to the FDF between 1981 and 2001. Data on wildland fires on federal lands were obtained from the USDA Forest Service, U.S. Fish and Wildlife Service, and the U.S. Park Service. Climate data were obtained from the National Oceanic and Atmospheric Administration (2003a, b). Data for annual housing counts and population for the estimation period were provided by the Florida Bureau of Economic and Business Research (2002), poverty data by the U.S. Census Bureau (2002), police data by the Florida Department of Law Enforcement (2002, unpublished data, available upon request), and unemployment data by the U.S. Department of Labor Bureau of Labor Statistics (2002). 


\section{Results}

The parameter estimates for the three models are displayed in Table 16-4. All three models are broadly significant, with most parameter estimates significant at the $1 \%$ level and most signs in the expected directions. The impacts of prescribed burning and wildfire are similar in all models, at least for the first few years. The effect of past wildfire on current wildfire acreage and intensity is longer lasting than on ignitions. Past

\begin{tabular}{|c|c|c|c|c|c|c|}
\hline \multirow[b]{2}{*}{ Independent variables } & \multicolumn{2}{|c|}{ Event (ignitions) } & \multicolumn{2}{|c|}{ Area (In area) } & \multicolumn{2}{|c|}{ Effect (In intensity) } \\
\hline & Coefficient & $P$ value & Coefficient & $P$ value & Coefficient & $P$ value \\
\hline Wildfire lag 1 & -0.386 & 0.00 & & & & \\
\hline Ln Wildfire lag 1 & & & -0.282 & 0.00 & -0.336 & 0.00 \\
\hline Wildfire lag 2 & -0.500 & 0.01 & & & & \\
\hline Ln Wildfire lag 2 & & & -0.266 & 0.00 & -0.230 & 0.00 \\
\hline Wildfire lag 3 & -0.990 & 0.25 & & & & \\
\hline Ln Wildfire Lag 3 & & & -0.201 & 0.00 & -0.227 & 0.01 \\
\hline Wildfire lag 4 & -0.804 & 0.74 & & & & \\
\hline Ln Wildfire Lag 4 & & & -0.217 & 0.00 & -0.254 & 0.01 \\
\hline Wildfire lag 5 & -2.448 & -0.37 & & & & \\
\hline Ln Wildfire lag 5 & & & -0.213 & 0.00 & -0.153 & 0.08 \\
\hline Wildfire lag 6 & -7.234 & 0.00 & & & & \\
\hline Ln Wildfire lag 6 & & & -0.199 & 0.00 & -0.308 & 0.00 \\
\hline Wildfire lag 7 & -1.954 & 0.17 & & & & \\
\hline Ln Wildfire lag 7 & & & 0.165 & 0.77 & 0.176 & 0.04 \\
\hline Wildfire lag 8 & 2.589 & 0.12 & & & & \\
\hline Ln Wildfire lag 8 & & & 0.103 & 0.11 & 0.144 & 0.13 \\
\hline Wildfire lag 9 & -2.054 & 0.17 & & & & \\
\hline Ln Wildfire lag 9 & & & -0.132 & 0.04 & -0.096 & 0.28 \\
\hline Wildfire lag 10 & 1.392 & 0.17 & & & & \\
\hline Ln Wildfire lag 10 & & & -0.136 & 0.02 & -0.205 & 0.01 \\
\hline Pres. Burn current & -1.515 & 0.00 & & & & \\
\hline Ln Pres. Burn current & & & -0.199 & 0.03 & -0.389 & 0.00 \\
\hline Pres. Burn lag 1 & -0.644 & 0.01 & & & & \\
\hline Ln Pres. Burn lag 1 & & & -0.102 & 0.356 & -0.217 & 0.17 \\
\hline Pres. Burn lag 2 & -0.247 & 0.23 & & & & \\
\hline Ln Pres. Burn lag2 & & & -0.509 & 0.00 & -0.658 & 0.00 \\
\hline $\begin{array}{l}\text { Housing Density (dwellings/ } \\
\text { for. ac) }\end{array}$ & -1022.68 & 0.05 & -7224.31 & 0.00 & -6006.95 & 0.03 \\
\hline Unemployment rate (\%) & -7.103 & 0.00 & -9.937 & 0.06 & -29.032 & 0.00 \\
\hline Poverty rate (\%) & -2.122 & 0.00 & 3.654 & 0.07 & 4.640 & 0.10 \\
\hline Population & 7.953 & 0.01 & 33.639 & 0.00 & 5.166 & 0.70 \\
\hline Police & -1.795 & 0.01 & -1.89 & 0.41 & 6.978 & 0.10 \\
\hline Niño-3 SST anomaly $\left({ }^{\circ} \mathrm{C}\right)$ & -0.334 & 0.00 & -0.310 & 0.01 & -0.658 & 0.00 \\
\hline NAO anomaly $\left({ }^{\circ} \mathrm{C}\right)$ & 0.294 & 0.00 & 0.883 & 0.00 & 1.149 & 0.01 \\
\hline 1998 dummy & 0.979 & 0.00 & 2.200 & 0.00 & 3.753 & 0.00 \\
\hline Log-likelihood & -1 & & & & & \\
\hline Observations & & & & & & \\
\hline Wald test statistic & & & & & & \\
\hline Wald significance & & .00 & & .00 & & 00 \\
\hline
\end{tabular}


wildfire reduces current rates of ignitions for only $5 \mathrm{yr}$ compared to $10 \mathrm{yr}$ for wildfire acreage and intensity.

Almost all of the wildland-urban interface variables (population, poverty, unemployment, housing density, and police) were highly significant in all three models. Table 16-5 compares the direction of the impacts of the wildland-urban interface variables for each model. Higher rates of unemployment, housing density, and population are all associated with statistically significant higher risks of ignition and area burned by wildfire. Unemployment and housing density are also correlated with increased wildfire intensity. Poverty rates and number of police in the county produce opposite impacts on ignitions and wildfire area and intensity. Poverty rates are negatively related to ignitions but positively related to area burned and wildfire intensity. The higher the poverty rate, the lower the probability of ignition, but once ignited the resulting wildfires tend to be larger and more intense in poorer counties. Likewise, the number of police in a county are correlated with reduced ignitions, but the resulting wildfires in those counties, although smaller, tended to be are more intense and therefore likely to cause more damage.

The confounding results between the various models may be explained in part by the findings of Butry et al. (2002). They used GIS to characterize and compare fire-affected zones in Florida by population demographics, road density, forest stand attributes, forest fragmentation, and sources and frequency of wildfire ignition. Butry's group found that more prescribed burning and lower amounts of wildfire are associated with counties with younger, less educated, and lower income populations. These areas occur predominately in rural areas with predominately slash pine forest stands managed for timber production. Counties with less prescribed burning and more wildfire, however, tended to be dominated by privately owned, highly fragmented bald cypress-water tupelo forests located on more valuable properties in counties dominated by older, wealthier populations and higher housing prices-the wildland-urban interface. Indeed, $75 \%$ of all wildfires in Florida occurred in wildland-urban interface areas in which no prescribed burning permits had been issued in recent decades.

All three of the WPF models predict that counties with high unemployment and lower economic activity experience fewer wildfire ignitions and lower amounts of area burned at lower intensities by wildfire. These tend to be in the rural areas of the Panhandle and North Central Florida dominated by forests managed for timber production with high rates of prescribed burning. In contrast, wildland-urban interface counties with lower unemployment and higher economic activity, tend to have less prescribed burning and more wildfire. These wildland-urban interface counties also tend to have higher populations which are correlated with more ignitions, wildfire acreage, and more intense wildfire. Densely populated urban areas (as opposed to the less densely populated wildland-urban interface areas) tend to have less risk of wildfire as evidenced by counties with higher housing density having fewer ignitions and fewer wildfires with lower intensities.

In summary, the more poverty in a county, the lower the rate of wildfire ignitions but the larger the subsequent area of acreage burned once ignited. Fewer fire fighting resources available for initial attack in poorer counties is the likely cause of the increased area burned in poorer counties. The result that counties with more police experience fewer wildfires has two potential explanations. First, counties with large cities and urban populations tend to have more police and also less wildfire. Second, police in the wildland-urban interface play an important role in reducing arson related wildfire ignitions (Donoghue and Main, 1985), the most common cause of wildfire ignition in Florida (Florida Protection Bureau, 2004). However, since the wildland-urban interface areas of Florida tend to have less prescribed burning, once an ignition occurs, the resulting wildfires tend to be more intense due to higher fuel loads. 


\section{Managing Wildfire in the Wildland-Urban Interface}

To effectively reduce fire hazards, homeowners, planners, and firefighters should conduct risk assessments across multiple scales ranging from a single residential lot to an entire landscape. At the residential lot level, extensive work has been done, and homeowners have a variety of tools to assess risk. The most frequently visited internet sites include Firesafe (www.firesafecouncil. org), Firefree (www.firefree.org), Firewise (www. firewise.org), and Firesmart (www.partnersinprotection.ab.ca) (International Code Council, 2008). In their report, International Code Council (2008) identified several key messages to homeowners. First, wildland fires are natural and have ecosystem functions. The second message is educational. Individuals must recognize the potential dangers associated with living in fire-prone areas. In addition, homeowners need to learn different mitigation techniques to reduce risks. Often, mitigation techniques are the focus of internet sites with respect to reducing fire risk to homeowners and recognizing the potential dangers. Third, there needs to be some type of incentive to motivate people. For instance, Bend, OR has a free program for wildland-urban interface homeowners to dispose of their flammable yard waste (www.firefree.org). Often, these actions must be done collectively by a homeowner and his/her neighbors, hence, the importance of a community approach to reducing fire risk.

The International Code Council (2008) report and Firewise (www.firewise.org) also recognize that the community is critical to reducing fire risk to homeowners. In fact, the community links neighbors into a comprehensive plan with the acknowledgment that a strong community risk plan is only as good as the weakest participant. In collaboration with communities, local and state agencies also play a critical role through future land-use planning, development of building codes and standards, as well as environmental standards, and the framework for disaster preparedness (International Code Council, 2008). Firewise Communities (www.firewise.org) can provide the most updated information on risk mitigation, coordinate activities so that homeowners can work as a communal unit toward a common goal, create incentives, and maintain continuity from year to year.

A number of mitigation strategies and protocols have been developed for different regions of the United States, and it is not the purpose of this chapter to review all of them or to report their content. Instead, we report some of the commonalities across strategies. There are two zones to assess for a residential lot with respect to fire hazard: context and content. Context refers to the location of the residential lot with respect to the natural vegetation and within the subdivision. Context basically defines the wildland fuel component and includes the disturbance regime, weather patterns, topography, and site history (Long and Randall, 2004). Similarly, it begins to define the type of wildland fire (e.g., surface or crown fire), the seasonality, and whether it is likely to burn through a community. Context also includes housing density. A burning home generates significantly more heat than burning vegetation and can emit large pieces of burning material that may ignite neighboring homes (Mell et al., 2010). Higher housing densities have a greater potential for structure to structure ignitions, but at this time we do not know what the threshold may be for an increased probability of a structure ignition from embers generated by a structural fire.

Content refers to the residential lot itself and is known as the home ignition zone. The home ignition zone accounts for flammable items on the lot and around the house (www.firewise.org). It includes such items as the trees, shrubs, ornamental beds, grass, out buildings, decks, fences, and fire woods-items that can burn and/or carry a fire. The home ignition zone also includes the structure itself, particularly construction materials such as wood shingles and siding, open soffits, vinyl soffits, and attached wood decks and fences (Long and Randall, 2004). Construction material plays a particularly important role with respect to types of ignition.

There are three ways a home can ignite: firebrands or embers, direct flame contact, and radiant heat. Firebrands are floating embers generated by burning vegetation or structures that can land on flammable items and ignite them. Manzello et al. (2009) observed that just a single 50-mm ember can ignite a dry cedar shingle and determined that airflow and the trapping of firebrands in small crevices played a critical role in ignition. Based on ignition tests, the critical fuel-bed angle for ignition is between 90 and $135^{\circ}$ (Manzello et al., 2009). Similarly, radiant heat can ignite, melt, or damage materials (e.g., vinyl soffits, siding, and windows), which may expose other flammable materials to possible ignition (Long and Randall, 2004). For instance, a burning shrub, outside a vinyl window with single-pane glass, may cause the window to break or melt, thereby enabling embers to enter the house increasing the probability of an ignition. 
To minimize likelihood of home ignition, a homeowner must eliminate the potential for ignition and interrupt the path of a wildland fire as it approaches his/her home. A homeowner does this by creating a defensible space (Table 16-6). Research by Cohen (2000) suggests a minimum

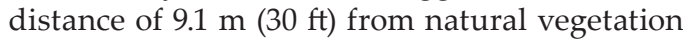
on level surfaces and possibly greater than 30.5 $\mathrm{m}$ (100 ft) for house slopes. Aesthetically, it is not necessary to remove all vegetation from residential lots. Ornamental beds should be separated by areas that will not burn (e.g., managed grass); plants should be pruned regularly and dead material removed to reduce fire ladders; plants themselves should be isolated and not overlapping, and beds and plants should be at least 1.5 $\mathrm{m}$ (5 ft) from any structure or flammable material (e.g., firewood) (Long and Randall, 2004). Selection of plant material for an ornamental bed should be based on a plant's flammability characteristic (White and Zipperer, 2010). For instance, plants with low flammability could be placed in beds $1.5 \mathrm{~m}$ from the house, whereas plants with high-flammability characteristics would be placed in beds at greater distances from the house (e.g., $9.1 \mathrm{~m})$. In other words, a homeowner can create an aesthetically pleasing landscape yard but must be aware that it takes only one weak point for ignition to occur during a wildland fire (Long and Randall, 2004).

The creation of a defensible space for a homeowner and a community is primarily behavioral, based on "rules of thumb," with the fundamental belief that if homeowners change their behavior toward reducing fire hazards, wildland fire risks will be reduced. Recently, Maranghides and Mell (2009) conducted a post-fire assessment to evaluate structural ignitions of a wildlandurban community during the Witch and Guejito fires in California. They reported that more than $50 \%$ of the structures were ignited within $3 \mathrm{~h}$ after the main fire front hit the community; $67 \%$ of the homes were ignited directly or indirectly by embers; $40 \%$ of the structures destroyed were on the perimeter, as compared to $25 \%$ in the interior of the community; and defensive actions were effective in reducing losses from more than $37 \%$ to 30\% (Maranghides and Mell, 2009). Even with detailed analyses, Maranghides and Mell (2009) were unable to determine whether embers from the wildland fire or structural fires ignited homes. Further, they were unable to determine the reach of the wildland fire into the community itself; however, limited data did indicate that the wildland fire ignited structures $0.2 \mathrm{~km}$ from the perimeter. Their analyses point out the importance of conducting post-fire studies, laboratory
Table 16-6. Ten tips often used to encourage homeowners to reduce fire risk. $\dagger$.

1 Define your defensible space.

2 Reduce flammable brush around your home and under nearby trees.

3 Prune or remove trees.

4 Keep grass and weeds cut low.

5 Clear wood piles and building materials away from your home.

6 Keep your yard and roof clean.

7 Keep address signs visible.

8 Choose fire-resistant building materials and lawn furniture.

9 Recycle yard debris-avoid burning.

10 Be prepared to respond to wildfire.

+ http://www.firefree.org/images/uploads/dcp_firefreebrochure_web.pdf

and field experiments on ember ignition, and the need for models to capture not only fire behavior but also local differences due to terrain, weather, vegetation types, and housing density.

Federal and state agencies have implemented strategies to reduce fire hazards in wildlands through different management techniquesprescribed fire, mechanical thinning, which includes mastication, chipping, mulching and biomass removal, and hand thinning to increase crown heights (International Code Council, 2008). These techniques are used to decrease the spread rate, intensity, and flame length of the fire, thus making the fire more controllable and less likely to spread into developments and communities (Mell et al., 2010). The efficacy of these treatments in altering wildland fire behavior for a range of environmental conditions still needs to be established (Carey and Schumann, 2003). In addition, the use of prescribed fires in wildland-urban communities is becoming limited as housing densities increase. The seasonal window of conducting prescribed fires is limited, and the implementation costs are becoming prohibitive. Consequently, the amount of area actually treated at one time may be less than management objectives (Yoder et al., 2004).

\section{Case Study 2: How Much Prescribed Fire is Optimal?}

Next, we present a case study for applying economic models to analyze the tradeoffs involved in using fuels management to reduce wildfire risk in the wildland-urban interface. The case study is derived from Mercer et al. (2007) and develops a dynamic stochastic programming and Monte Carlo simulation to evaluate 
the tradeoffs between fuels management (prescribed fire) and resulting economic damages from wildfires. This approach is directed at strategic decision-making for wildfire management: how to allocate fuels management resources to maximize societal welfare in the long run.

In general, determining the publicly optimal amount of prescribed burning requires solving a stochastic dynamic optimization problem. Therefore, to find the optimal levels of prescribed fire (or other vegetation management) inputs for wildfire risk reduction, the sum of expected current and future net present value of welfare is maximized as follows:

$$
\begin{aligned}
& \max _{x_{t}} A=E\left\{V W_{t}-\mathbf{v}(\mathbf{x})^{\prime} \mathbf{x}_{\mathbf{t}}+\sum_{i=t+1}^{T} e^{-r i}\left[V W_{i}-\mathbf{v}(\mathbf{x})^{\prime} \mathbf{x}_{\mathbf{i}}\right]\right\} \\
& \text { and } \\
& W_{t}=W\left(\mathbf{Z}_{\mathbf{t}}, \mathbf{W}_{\mathbf{t}-\mathbf{j}}, \mathbf{x}_{\mathbf{t}-\mathbf{k}}\right)+\varepsilon_{t}, \mathbf{x}_{\mathbf{t}} \geq 0(\forall t)
\end{aligned}
$$

where $A$ is the maximization criterion (a welfare measure), $V$ is the net value change per unit area of wildfire, $W_{t}$ is area (acres) burned by wildfire ${ }^{4}$ in year $t$. $\left(W_{t}\right.$ could, alternatively, be expressed as a quantity measure of resources "saved" by applying resource inputs. In that case, $V$ would be a positive number, reflecting positive values. As currently expressed in Eq. [1], $V$ would be a negative value per unit, measuring damages per unit of wildfire realized.) $\mathbf{v}$ is a vector of the costs per unit area of suppression, presuppression, and vegetation management inputs. (The "price" to the economy would be the net welfare change arising from the diversion of resources to vegetation management and away from other economically productive activities in the economy; in other words, this is the opportunity cost of foregone uses of these resources in the economy.) $\mathbf{x}=\left(\mathbf{x}_{\mathrm{t}^{\prime}} \mathbf{x}_{\mathrm{t}+1^{1}}, \ldots, \mathbf{x}_{\mathrm{T}}\right)$ is a vector of the amount of suppression, presuppression, and vegetation management inputs for year $t$ through $T$ (the planning horizon), $\mathbf{x}_{\mathbf{t}-\mathbf{k}}$ is a vector of $k$ lags of prescribed burn area, $\mathbf{Z}_{t}$ are exogenous inputs to wildfire production including stochastic climate variables, and $\mathbf{W}_{t-j}$ is a vector of $j$ lags of wildfire area, and $r$ is the discount rate.

Solving this optimization problem produces a $T \times 1$ vector of optimal input quantities, $\mathbf{x}$, and a $T \times 1$ vector of wildfire quantities, $W_{t^{\prime}}$ over time. The uncertainty associated with random events (e.g., errors in prediction of weather) means that $W(\cdot)$, is known only with error, complicating the solution process. In the presence of such error, simulation techniques may be used to identify, for example, the amounts of prescribed burning most likely to maximize the welfare criterion. Optimization models like Eq. [3] may involve as many choice variables as periods in the simulation, making them difficult to solve. Alternatively, the problem can be simplified to identifying the single optimal (stationary) policy from the set of possible policies that yields the highest expected net welfare benefits and which is consistent with any utility function that demonstrates nonincreasing marginal utility.

\section{The Simulation Model}

Identifying the long-run expected impact of prescribed fire requires accounting for variable weather and the uncertainties associated with the "true" form of Eq. [1]. While Eq. [3] was estimated using historical data on fire output and wildfire production inputs, observed wildfire output always differs from that predicted by an empirical model because of the random nature of the phenomenon and the imprecision of model specification. To identify the "best" level of prescribed fire to apply in a fire-prone landscape, Mercer et al. (2007) first estimated two versions of Eq. [3]-one expressing wildfire output in area burned and one in intensity-weighted area burned. (Tables 16-1 and 16-2). Research has shown that wildfire intensity is closely related to the resulting damages to forests (Kennard, 2004), so measuring how prescribed fire affects the intensity of wildfire output should provide a more accurate prediction of the impacts of prescribed fire on wildfire damages.

Next, the results from the empirical estimates of Eq. [3] were used to forecast the expected damages from wildfire under different prescribed fire scenarios for Volusia County, which was representative of the fire-prone wildland-urban interface landscape of Florida. Forecasts of annual wildfire activity were made for $100 \mathrm{yr}$ into the future. The $100-y r$ realization of wildfire output was done by (i) selecting a fixed level of prescribed fire to apply every year, (ii) randomly selecting the values of two climate variables found to influence wildfire in Florida (a measure of El Niño and a measure of the North Atlantic Oscillation), (iii) randomly selecting a forecast error for wildfire area burned and wildfire intensity-weighted area burned from the historical distribution of weather factors and from prediction errors, and then (iv) calculating the total annual expected wildfire damages and suppression costs and the annual cost of applying the fixed amount of prescribed fire to the county. The final step was to vary the amount of prescribed fire chosen in the first step and then repeat the following steps. This process 
was continued, starting from 2023 ha (5000 acres) prescribed burned per year, up to about 40,500 ha $(100,000$ acres) per year (out of 127,000 ha [313,000 acres] of forest in the county). After all of these simulations were completed, the total, long-run discounted cost plus losses associated with wildfire and prescribed fire were compared across all levels of prescribed fire to identify the level of prescribed fire where the costs and losses were smallest.

Models were estimated for fire at the county level. Two county fixed-effects time series models were estimated: Model 1, intensity-weighted area burned; Model 2, area burned. (A "fixed effects" time series regression model assumes that dif- prescribed fire services had a long-run elasticity of about 0.54 . This indicates that the cost of prescribed fire per acre would increase twice as fast as the increase in the areal increase in prescribed fire. This extra cost associated with higher levels of prescribed fire was included in the cost plus loss simulations.

The simulations (Fig. 16-3 and 16-4) showed that the optimal levels of prescribed fire depend on whether wildfire is measured in terms of area burned or in intensity-weighted acres. Figure 16-3 shows the impact of prescribed fire on both wildfire intensity-weighted acres and on the losses and costs associated with wildfire and prescribed fire applied to achieve ferences across units (counties in our case) can be captured in the constant term.) The dependent variables for the two models were: Model 1: intensityweighted acres per acre of forest area in the county in the year; Model 2: total wildfire area burned per acre of forest area in the county.

The losses associated with wildfire were calculated based on the 1998 wildfires (Butry et al., 2002). Two versions of losses were generated: One version assembled timber and housing losses and suppression expenditures in terms of market values-prices times quantities. Another version assembled losses in terms of social welfare-consumer plus producer. Due to data limitations suppression expenditures were not included in the social welfare analysis.

\section{Results}

The original statistical models, relating fire area burned and fire intensity-weighted area burned, show that prescribed burning at the county level has a large, statistically significant effect on both intensity-weighted area burned and on area burned in the county. The elasticity of intensity-weighted area burned with respect to prescribed fire was -0.9 in the short-run ( $0-2$ yr) and -0.31 in the long-run $(>2 \mathrm{yr})$. The elasticity of wildfire area burned with respect to prescribed fire was -0.72 in the short run and -0.28 in the long run.

Mercer et al. (2007) also estimated a model found for the supply of prescribed fire services (i.e., the human and capital inputs required for performing prescribed burns), which showed that

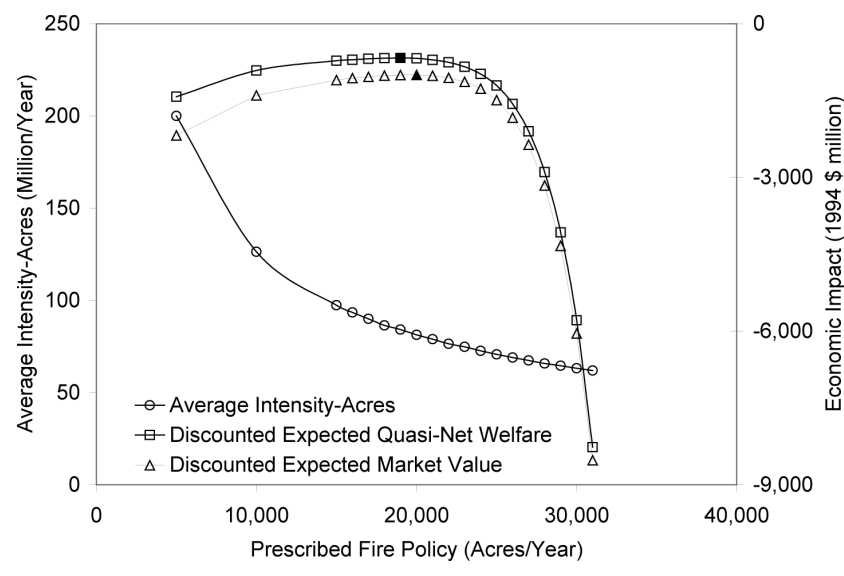

Fig. 16-3. The simulated schedule of input-output combinations derived from the intensity-weighted risk model. The amounts of prescribed burning yielding the maximum of net value change minus cost (symbols shaded black) are 19,000 acres/year for the quasi-net welfare analysis and 20,000 acres/year for the market value analysis. (from Mercer et al., 2007).

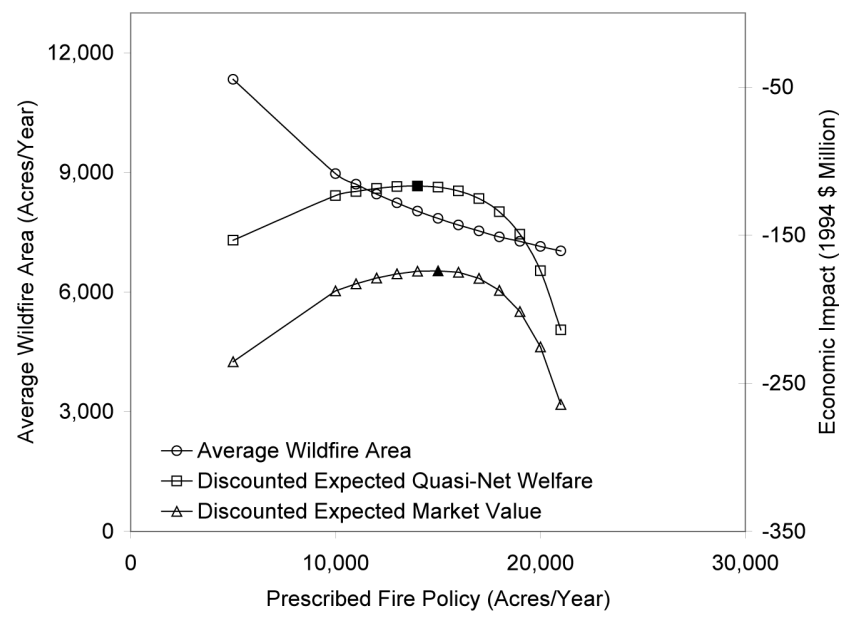

Fig. 16-4. The simulated schedule of input-output combinations derived from the areal risk model; amounts of prescribed burning yielding the maximum of net value change minus cost (symbols shaded black) are 14,000 acres/year for the quasi-net welfare analysis and 15,000 acres/ year for the market value analysis. (from Mercer et al., 2007). 
these levels of losses and costs. Figure 16-4 shows the same, but in terms of area burned related losses instead of intensity-weighted area burned related losses. Figure 16-1 shows that the expected value of losses plus costs is minimized when prescribed fire is set at about 19,000 acres per year in Volusia County, Florida. Figure 16-2 shows that the prescribed fire area of 14,000 acres per year minimizes net value change plus costs. From 1994 to 2001, Volusia County averaged about 5260 ha (13,000 acres) per year, which is close to the amount justified based on the area burned effect of prescribed fire. But, this is about $30 \%$ less than the amount that would be justifiable based on the intensityweighted area burned measure.

\section{Summary}

In this chapter we provided an overview of the socioeconomic and ecological effects and trends of wildfire in the wildland-urban interface, methods for assessing wildfire risk in the wildland-urban interface, approaches to managing the wildfire problem including fuels management, home construction and design, and community action programs. This overview is combined with two case studies analyzing wildfire risk and the use of prescribed fire to reduce that risk in the Florida wildland-urban interface.

Each year, federal agencies respond to about 79,000 wildfires and local agencies respond to about 356,800 brush, grass, and forest fires. The costs in terms of life, property, and resources are devastating. For example, in an average year wildfires kill 21 firefighters, destroy 1179 residences, 1156 outbuildings, and 42 businesses and result in $\$ 3$ billion in federal outlays to fight wildfires. Furthermore, the costs of wildfire have increased dramatically over the past few decades. Nine of the 10 most costly wildfires occurred since 1990 and have resulted in a total of about $\$ 10$ billion in damages, 10,000 homes damaged, and the loss of at least 55 lives. As a result, managing wildfire has become a central focus of federal, state, and local land management agencies.

The number of wildfires, area burned, and resulting damages have continued to grow over the past 25 years. Several factors are responsible for this, but the two most important factors under human control are wildfire suppression policies and development in fire-prone ecosystems. The success of federal wildfire suppression efforts during the 20th century has created a series of ecological changes that have actually increased the risk of wildfire and made controlling them more difficult and expensive. But, the rapid growth of the wildland-urban interface is actually the single most important factor for the increased costs associated with wildfire.

Solving the wildland-urban interface wildfire management problem requires a series of efforts at a number of levels. We need to improve our ability to assess the risk of wildfire facing communities across the nation, but particularly in the West and Southeast, and use this information in local and regional planning to protect the current at-risk communities and reduce the number of homes in areas with high risk of wildfire. Efforts to mitigate wildfire damages through creating defensible spaces around homes and other structures, and reducing fuel loads through prescribed fire and other vegetation management techniques need to be enhanced. In addition, we need to do a better job of allocating scarce wildfire management resources among suppression, prevention, and mitigation activities.

The two case studies in this chapter serve as examples of empirically estimating wildfire risk as a function of nonhuman (weather, climate, ecology) and human (wildfire management, economic and social conditions) and using the results of the risk analysis to determine the optimal prescribed burning policies in the Florida wildland-urban interface. The case studies suggest that (at least in Florida) the more rural the wildland-urban interface, the fewer wildfire ignitions and resulting acreage burned. This is probably because the more rural areas of the wildland-urban interface in Florida are dominated by highly managed forests, where prescribed burning is common and where managerial inputs to production forestry tend to lower risks of catastrophic wildfire. Moving along the wildland-urban interface continuum to more densely populated areas with more valuable properties located near water resources, the forests are less intensively managed, prescribed burning is rare, and the number of ignitions and the area burned per unit of space and time are higher. Examining the tradeoffs between prescribed fire treatments and damages from wildfire, the second case study shows that fuels management (prescribed fire in this case) is a good investment, at least in Florida. At the prescribed fire levels being applied by public and private landowners in Volusia County, Florida, the long-run benefit/cost ratio of prescribed fire is close to or greater than unity.

One overall implication is that it is crucial that analyses of wildfire risk for regions with 
high populations and varying economic indicators include socioeconomic (human) in addition to physical (nonhuman) factors. Omissions of socioeconomic conditions can lead to mischaracterizations of the factors underlying wildfire risk and result in inefficient allocation of scarce wildfire management resources. In addition, fire managers and decision makers should recognize the critical role that humans play in affecting wildfire risk. Humans set fires, put out fires, allow fuels to accumulate around their homes and property, and construct barriers to fire spread (e.g., roads). The socioeconomic economic conditions in which humans live affect the degree to which these kinds of intentional and unintentional interventions into fire regimes are manifested. For example, unemployment and poverty are indicators of the resources available for wildfire management, the effectiveness of fire awareness programs, the frequency of arson, and economic activities that might be linked to accidental ignitions (e.g., rail and automotive traffic). Policymakers seeking ways to minimize damages and restore ecosystems in or near the wildland-urban interface should be aware of these effects and take into account the many ways that people affect wildfire risk.

\section{References}

Agar, A., M. Finney, and A. McMahan. 2006. A wildfire risk modeling system for evaluating landscape fuel treatment strategies. USDA Forest Service Proc. RMRS-P-41.

Ahrens, M. 2010. Brush, grass, and forest fires. http://www. nfpa.org/assets/files//PDF/BrushGrassForestExecSum.pdf (accessed 18 July 2012). Fire Analysis and Research Division, National Fire Protection Association, Quincy, MA.

Andrews, P.L., and C.D. Bevins. 1999. BEHAVE fire modeling system: Redesign and expansion. Fire Manage. Notes 59(2):16-19.

Armstrong, G.W. 1999. A stochastic characterization of the natural disturbance regime of the boreal mixedwood forest with implications for sustainable forest management. Can. J. For. Res. 29:424-433. doi:10.1139/x99-010

Bachelot, D, J. Lenihan, and R. Neilson. 2007. Wildfire and global climate change: The importance of climate change for future wildfire scenarios in the western United States. http://www.pewclimate.org/docUploads/RegionalImpacts-West.pdf (accessed 19 July 2012). Pew Center on Global Climate Change, Arlington, VA.

Bachman, A., and B. Allgöwer. 2001. A consistent wildland fire risk terminology is needed! Fire Manage. Today 61(4):28-33.

Barnett, T.P., and J. Brenner. 1992. Prediction of wildfire activity in the southeastern United States. Regional Climate Center Research Paper 011592. South Carolina Water Resources Commission, Columbia, SC.

Brenner, J. 1991. Southern oscillation anomalies and their relation to Florida wildfires. Fire Manage. Notes 52(1):28-32.

Brillinger, D.R. 2003. Three environmental probabilistic risk problems. Stat. Sci. 18(4):412-421.
Butry, D.T., J.M. Pye, and J.P. Prestemon. 2002. Prescribed fire in the interface: Separating the people from the trees. In: K.W. Outcalt, editor, Proceedings of the Eleventh Biennial Southern Silviculture Research Conference. USDA Forest Service General Technical Report GTR-SRS-48. USDA, Asheville, NC. p. 132-136.

Carey, H., and M. Schumann. 2003. Modifying wildfire behavior-The effectiveness of fuel treatments, the status of our knowledge. Southwest Region Working Paper 2. National Community Forestry Center, Providence, RI.

Cohen J.D. 2000. Preventing disaster: Home ignitability in the wildland-urban interface. J. For. 98: 15-21.

Cox, D. 1972. Regression models and life tables. J. Royal Stat. Soc. B 34:187-202.

Cumming, S.G. 2001. A parametric model of the fire-size frequency distribution. Can. J. For. Res. 31:1297-1303. doi:10.1139/x01-032

Davis, L., and R.W Cooper. 1963. How prescribed burning affects wildfire occurrence. J. For. 61:915-917.

Donoghue, L.R., and W.A. Main. 1985. Some factors influencing wildfire occurrence and measurement of fire prevention effectiveness. J. Environ. Manag. 20, 87-96.

Donovan, G.H., and T.C. Brown. 2007. Be careful what you wish for: The legacy of Smokey Bear. Front. Ecol. Environ. 5:7379. doi:10.1890/1540-9295(2007)5[73:BCWYWF]2.0.CO;2

Donovan, G.H., and D.B. Rideout. 2003. A reformulation of the cost plus net value change $(\mathrm{C}+\mathrm{NVC})$ model of wildfire economics. For. Sci. 49, 318-323.

Finney, M.A. 1998. FARSITE: Fire area simulator: Model development and evaluation. USDA Forest Service Research Paper RMRS-RP-4.

Finney, M.A. 2005. The challenge of quantitative risk analysis for wildland fire. For. Ecol. Manage. 211:97-108.

Finney, M.A., P.L. Andrews. 1999. FARSITE-A program for fire growth simulation. Fire Manage. Notes 59(2):13-15.

Florida Bureau of Economic and Business Research. 2002. Long-term economic forecast 2001. Vol. 1 and 2. [CD.] Univ. of Florida, Gainesville.

Florida Protection Bureau. 2004. Wildfire statistics 1981-present. http://flame.fl-dof.com/General/ (accessed 28 May 2004). Florida Division of Forestry, Tallahassee.

Garcia, C.V., P.M. Woodard, S.J. Titus, W.L. Adamowicz, and B.S. Lee. 1995. A logit model for predicting the daily occurrence of human caused forest fires. Int. J. Wildland Fire 5:101-111. doi:10.1071/WF9950101

Gill, A.M., K.R. Christian, P.H.R. Moore, and R.I. Forrester. 1987. Bush fire incidence, fire hazard and fuel reduction burning. Aus. J. Ecol. 12:299-306. doi:10.1111/j.1442-9993.1987. tb00950.x

Glickman, D., and B. Babbitt. 2001. Urban wildland interface communities within the vicinity of federal lands that are at high risk from wildfire. Federal Register 66 (3), 751-777.

Governor's Wildfire Response and Mitigation Review Committee. 1998. Through the Flames...An assessment of Florida's wildfires of 1998, final report. http://www. dca.state.fl.us/fdem/dem/gwfrmrc/report/lewis2.htm (accessed 21 Apr. 2004).

Greene, W.H. 1997. Econometric analysis. 3rd ed. Prentice Hall, Upper Saddle River, NJ.

Hammer, R., S. Stewart, and V. Radeloff. 2008. Demographic trends, the wildland-urban interface, and wildfire management. Working Paper RSP-08-01. Rural Studies Program, Oregon State Univ., Corvallis, OR.

Holmes, T.P, J.P. Prestemon, J.M. Pye, D.T. Butry, D.E. Mercer, and K.L. Abt. 2004. Using size-frequency distributions to analyze fire regimes in Florida. In: R.T. Engstrom, K.E.M. Galley, and W.J. de Groot, editors, Fire in Temperate, Boreal and Montane Ecosystems, Proceedings of the Tall Timbers 22nd Fire Ecology Conference, 15-18 Oct. 2001. 
Tall Timbers Research Stn., Kananaskis Village, Alberta, Canada, p. 88-94.

International Code Council. 2008. The Blue Ribbon Panel report on wildland urban interface fire. http://www.iccsafe.org/gr/wildland-urban interfaceC/Documents/ BlueRibbonReport-Low.pdf (accessed 9 Nov. 2011).

Keeley, J.E., C.J. Fotheringham, and M. Morais. 1999. Reexamining fire suppression impacts on brushland fire regimes. Science 284:1829-1832. doi:10.1126/ science.284.5421.1829

Kennard, D.K. 2004. Depth of burn. In: Forest encyclopedia. http://www.forestencyclopedia.net (accessed 15 Jan. 2004).

Li, C., I.G.W. Corns, and R.C. Yang. 1999. Fire frequency and size distribution under natural conditions: A new hypothesis. Landscape Ecol. 14:533-542. doi:10.1023/A:1008116926563

Long, A.L., and C.K. Randall. 2004. Wildfire risk assessment guide for homeowners in the southern United States. Circ. Univ. Florida Cooperative Extension Service, Gainesville, FL.

Malamud, B.D., G. Morein, and D.L. Turcotte. 1998. Forest fires: An example of self-organized critical behavior Science 281:1840-1842. doi:10.1126/science.281.5384.1840

Manzello, S.L., S. Park, and T.G. Cleary. 2009. Investigation on the ability of glowing firebrands deposited within crevices to ignite common building materials. Fire Safety J. 44:894-900. doi:10.1016/j.firesaf.2009.05.001

Maranghides, A., and W.E. Mell. 2009. A case study of a community affected by the Witch and Guejito Fires. National Institute of Standards and Technology, Gaithersburg, MD.

Mell, W.E., S.L. Manzello, A. Maranghides, D. Butry, and R.G. Rehm. 2010. The wildland-urban interface fire problemCurrent approaches and research needs. Int. J. Wildland Fires 19:238-251. doi:10.1071/WF07131

Menakis J.P., J. Cohen, and J. Bradshaw. 2003. Mapping wildland fire risk to flammable structures for the conterminous US. In: K.E.M. Galley, R.C. Klinger, and N.G. Sugihara, editors, Proceedings of Fire Conference 2000: The First National Conference on Fire Ecology, Prevention and Management. Misc. Publ. 13. Tall Timber Research Station, Tallahassee, FL. p. 41-49.

Mercer, E., and J. Prestemon. 2005. Comparing production function models for wildfire risk analysis in the wildland urban interface. For. Policy Econ. 7:782-795. doi:10.1016/j. forpol.2005.03.003

Mercer, D.E., J.P. Prestemon, D.T. Butry, and J.M. Pye. 2007 Evaluating alternative prescribed burning policies to reduce net economic damages from wildfire. Am. J. Agric Econ. 89(1):63-77.

McLellan, S., and J. Brenner. 2003. Florida's communities at risk. Paper presented at the 2nd International Fire Ecology and Management Congress, Orlando, Florida, November 2003. http://www.ams.confex.com/ams/ pdfview.cgi?username=66092M (accessed 21 Apr. 2004).

National Fire Protection Association. 2009. Deadliest largeloss fires. http://www.nfpa.org/itemDetail.asp?category ID $=954 \&$ itemID $=44745 \& U R L=$ Research/Fire\%20statistics/Deadliest/large-loss\%20fires (accessed 19 July 2012). National Fire Protection Association, Quincy, MA.

National Institute of Standards and Technology. 2010 National Interagency Coordination Center wildland fire summary and statistics annual report: 2010. http://www. predictiveservices.nifc.gov/intelligence/2010_statssumm/ intro_summary.pdf (accessed 19 July 2012).

National Oceanic and Atmospheric Administration. 2003a El Niño-Southern oscillation sea surface temperature measures. ftp://ftp.ncep.noaa.gov/pub/cpc/wd52dg/data/ indices/sstoi.indices (accessed 10 Oct. 2002).

National Oceanic and Atmospheric Administration. 2003b. Standardized northern hemisphere teleconnection indices. ftp://ftp.ncep.noaa.gov/pub/cpc/wd52dg/data/indices/ tele_index.nh (accessed 11 Apr. 2003).
Prestemon, J.P., J.M. Pye, D.T. Butry, T.P. Holmes, and D.E. Mercer. 2002. Understanding broad scale wildfire risks in a human-dominated landscape. Forest Sci. 48, 685-693.

Prestemon, J.P., D.E. Mercer, and J.M. Pye. 2008. Natural disturbance production functions. In: T. Holmes, K. Abt, and J. Prestemon, editors, The economics of forest disturbances. Springer, New York. p. 35-58.

Pye, J.M., J.P. Prestemon, D.T. Butry, and K.L. Abt. 2003. Prescribed burning and wildfire risk in the 1998 fire season in Florida. In: P. Omi, editor, Conference on Fire, Fuel Treatments and Ecological Restoration, 16-18 Apr. 2002, Ft. Collins, CO. USDA For. Serv. Gen. Tech. Rep. RMRS-P-29. p. 15-26.

Radeloff, V.C., R.B. Hammer, S.I. Stewart, J.S. Fried, S.S Holcomb, and J.F. McKeefry. 2005. The wildland-urban interface in the United States. Ecol. Appl. 15:799-805. doi:10.1890/04-1413

Rasker, R. 2009. Solutions to the rising costs of fighting fires in the wildland-urban interface. www.headwaterseconomics.org/wildfire.php (accessed 18 Sept. 2011). Headwaters Economics, Bozeman, MT.

Reed, S.E., H.E. Kretser, M.J. Glennon, L. Pejchar, and A.M. Merenlender. 2012. Faunal biodiversity at the urban-rural interface: Current knowledge, research priorities, and planning strategies. In: D.N. Laband, B.G. Lockaby, and W. Zipperer, editors, Urban-rural interfaces: Linking people and nature. ASA, CSSA, and SSSA, Madison, WI. p. 99-114, this volume.

Rideout, D.B., and P.N. Omi. 1990. Alternate expressions for the economic theory of forest fire management. Forest Sci. 36:614-624.

Schmidt K.M., J.P. Menakis, C.C. Hardy, W.J. Hann, and D.L. Bunnell. 2002. Development of coarse-scale spatial data for wildland fire and fuel management. USDA Forest Service Rocky Mountain Stn., Fort Collins, CO.

Steelman, T.A., and G.F. Kunkel. 2004. Effective community responses to wildfire threats: Lessons from New Mexico. Soc. Nat. Resour. 17:679-699. doi:10.1080/08941920490480697

Strauss, D., L. Bednar, and R. Mees. 1989. Do one percent of forest fires cause ninety-nine percent of the damage? For. Sci. 35, 319-328.

Theobald, D.M., and W.H. Romme. 2007. Expansion of the US wildland-urban interface. Landscape Urban Plan. 83:340354. doi:10.1016/j.landurbplan.2007.06.002

U.S. Census Bureau. 2002. Small Area Income and Poverty Estimates, State and County Estimates, 2002. http://www. census.gov/hhes/www/saipe/estimatetoc.html. Accessed on 3 Sep. 2002.

U.S. Department of Labor Bureau of Labor Statistics. 2002. Geographic profile of employment and unemployment. http://www.bls.gov/gps/home.htm (accessed 10 May 2002).

U.S. Government Accountability Office. 2009. Wildland fire management: Actions by federal agencies and congress could mitigate rising fire costs and their effects on other agency programs. GAO-09-444T. U.S. Government Accountability Office, Washington, DC.

USDA Forest Service. 2000. Managing the impact of wildfires on communities and the environment: A report to the President in response to the wildfires of 2000. USDA Forest Service, Washington, DC.

USDA Forest Service. 2004. Strategic plan for fiscal years 20042008, final report. USDA Forest Service, Washington, DC.

USDA Office of Inspector General. 2006. Audit report: Forest Service large fire suppression costs. Rep. 08601-44SF. http://www.usda.gov/oig/webdocs/08601-44-SF.pdf (accessed 18 Sept. 2011).

Westerling, A.L., A. Gershunov, and D.R. Cayan. 2002. Long lead statistical forecasts of area burned in western US 
wildfires by ecosystem province. Int. J. Wildland Fire 11:257-266. doi:10.1071/WF02009

Westerling, A.L., H.G. Hidalgo, D.R. Cayan, and T.W. Swetnam. 2006. Warming and earlier spring increase western U.S. forest wildfire activity. Science 313:940-943. doi:10.1126/ science. 1128834

Westerling, A.L., and T.W. Swetnam. 2003. Interannual to decadal drought and wildfire in the western United States. Eos Trans. AGU 84:545, 554-555. doi:10.1029/2003EO490001

White, R.H., and W.C. Zipperer. 2010. Testing and classification of individual plants for fire behavior: Plant selection for the wildland-urban interface. Int. J. Wildland Fires 19:213-227 doi:10.1071/WF07128

Yoder, J., D. Engle, and S. Fuhlendorf. 2004. Liability, incentives and prescribed fire for ecosystem management. Front. Ecol. Environ. 2:361-366. doi:10.1890/1540-9295(2004)002[0361:LIAPFF]2.0.CO;2

Zipperer, W.C. 2002. Urban influences on Forests. In: E.A. Macie and L.A. Hermansen, editors, Human influences on forest ecosystems: The southern wildland-urban interface assessment. Tech. Rep. SRS-GTR-55. USDA Forest Service Southern Research Stn., Asheville, NC. p. 73-91. 
